\title{
LEGISLATIVE RESTRICTIONS ON MARKETING INTEGRATION
}

\author{
Edith N. Cook*
}

The struggle of one type of business concern to protect itself against competitive encroachments either from new forms of business, or merely from additions to its ranks of more of the same type of competitors, ${ }^{1}$ is probably as old as man himself. For where self-interest resides, there one finds resourcefulness in the fashioning of protective weapons. And for each weapon that is removed, judicially or otherwise, from the hands of its fashioners, new ones spring forth from the fertile minds behind those hands. Even as early man devised tangible weapons to wield against encroaching competitors in the form of human or animal enemies who threatened his food supply, so the modern man eternally attempts to devise intangible weapons to wield against threats to his established form of livelihood.

The man in the business of marketing goods or services today finds his livelihood threatened, among other ways, by the competition created through the evolution of those new forms of distribution achieved by the horizontal or vertical integration of previously separate products or functions. Horizontally, the threat to existing merchandising patterns takes the form of integration in one business unit, or under common ownership, of what might be designated as unrelated lines of business or merely as the marketing of many goods or services instead of one or a limited number. Through vertical integration, the old-line seller is faced with combination in one unit of either production and distribution or the various stages of the distribution process itself.

To meet this competition, or the threat of it, resort is had to the legal weapon of protective legislation, though an attempt is made to disguise the real purpose in its use under the gaudy trappings of declarations that it is all done in the interest of protecting the public against practices dangerous to its health ${ }^{2}$ or practices promotive of monopoly. ${ }^{3}$ Such attack invites resistance, for the newly developing forms of dis.

* A.B., 1929, Goucher College; LL.B., I932, Columbia University. Assistant Administrative Attorney, Markcting Laws Survey.

${ }^{I}$ For a discussion of tha efforts of business to protect itself against this form of competition, see Silverman, Bennett and Lechliter, Control by Licensing Over Entry into the Market, supra this issue, an example of which is the adoption by mero occupational groups (barbers and beauty culturists, and other service trades) of a "professional" status with concomitantly stringent requirements set up for entry therein.

${ }^{3}$ See, infra, the discussion of legislation restricting the sale of food to food establishments, and the sale of drugs to registered pharmacists.

${ }^{3}$ See, infra, the discussion of restrictions on the retail merchandising of appliances by public utilities, on the ownership of theaters by motion picture producers, and on the wholesaling of groceries by the meat-packing companies. 
tribution also have wanted to survive and grow. Here, too, we find the struggle clothed in gaudy phraseology of "personal liberties" and the right of free men to engage in all lawful pursuits. In speaking of the Missouri anti-department store law of $1899,{ }^{4}$ the then President of the American Bar Association said: ${ }^{5}$

Did the lawmakers desire precedent for the attempted destruction of department stores, they could have found absolute prohibition of the carrying on of more than one business, under heavy penalties, among the discarded rubbish of the English law in statutes of the golden time when the might of kings controlled the right of subjects. It is unnecessary to state in this presence that long ago these impositions upon personal liberty were consigned, with many others of like import, to the dust heap.

No less immemorial is the struggle of the community to protect itself against the inordinate use of such weapons and counter-weapons, or against their use at all, where they may tend to give a certain class of men a monopoly of the trade without being sufficiently justified as a protection of public interest. That this struggle, too, is of ancient lineage, is eloquently witnessed by the proposition which the Emperor Zeno enacted in his constitution between 474 and 49r A.D.: 6

We decree that no one shall be permitted to exercise a monopoly in garments of any sort ... nor in any commodity serving as food, or put to any other use, nor in any fabric, be it of his own accord or in pursuance of an existing or proposed imperial edict or pragmatic sanction of our written decree, and that no one shall enter into an unlawful association not to sell certain commodities more cheaply than agreed. (International Monthly, No. 5, January-June, rgo2, pp. 478-479).

In a society which is rightly or wrongly based, at least theoretically, upon the idea of a free competitive economy, ${ }^{7}$ one would assume that side would prevail which did not foster a monopoly or monopolistic tendencies. Such is not always the case. Each side hurls the accusation of monopoly at the other, and to a certain extent each is right. Integration in distribution, like concentration in production, can produce monopolistic power which may be used to stifle competition. On the other hand, legislation sponsored by established forms of marketing enterprise, attempting to prohibit or restrict horizontal or vertical integration, itself operates in a monopolistic manner, even though its proponents frequently attempt to justify it

\footnotetext{
Mo. Acts 1899 , p. 72, discussed at note 13, infra.

(I927) 48 L. R. A. 26 r.

${ }^{\circ}$ See speech of Representative Littlefield on amendments to the Sherman Act, 36 CoNG. Rec. 1836 (1903).

7 The attempt to foster such an economy is eloquently attested by the growth and existence of a large body of both state and federal anti-trust legislation, and the long line of judicial opinion upholding it. See National Cotton Oil Co. v. Texas, 197 U. S. I15, I29 (1904), in which, in upholding the antitrust laws of Texas, the Supreme Court of the United States said: "It is enough to say that the idea of monopoly ... the notion of exclusiveness ... the suppression of competition by the unification of interest ... is ... the concern of the law to prohibit. ... And this concern and the policy based upon it has not only expression in the Texas statutes; it has expression in the statutes of othet states and in a well-known national enactment. According to them, competition, not combination, should be the law of trade. If there is evil in this it is accepted as less than that which may result from unification of interest, and the power such unification gives. And that legislatures may so ordain this court has decided."
} 
with the very argument that it is devised to prevent monopolistic practices. ${ }^{8}$ Necessarily, a law which attempts to restrict to a certain class of men the privilege of marketing certain products, is giving such class a monopoly of that trade, ${ }^{9}$ and setting up legislative barriers against the entrance of one-time outsiders therein. It would seem, therefore, that the courts would frown upon such legislative monopolies. Such, however, has not always been the result in cases testing the legality of such restrictive legislation. Broad concepts of state police power and the well-known judicial reluctance to invalidate a statute allegedly enacted under such power, come into operation..$^{10}$ If the control sought by the legislation can be related "reasonably"11 to the preservation of the public health, safety, morals or general welfare, the courts will approve it, thus perpetuating a limited monopoly in favor of established forms of business.

\section{Product INTEgration}

Legal action aimed at preventing the integration in one marketing unit of lines or products formerly marketed by separate types of business concerns has taken interpretation of the language of the Sherman Act to prohibit the vending of several forms: (I) the abortive anti-department store laws of the late nineteenth century; (2) restrictions on the retailing of appliances by public utilities; (3) an "groceries" by those engaged in the meat-packing industry; (4) the recent restaurant meals served by drugstores and five-and-tens; (5) restrictions on motor vehicle laws designed to protect the restaurateur from the competition of low-cost, tipless dealers engaging in any other line of business; (6) restrictions on the retailing of alcoholic beverages in connection with other types of commodities; (7) a long history of pharmacy laws restricting the sale of nearly all kinds of drugs and medicines to registered pharmacists; and (8) the recent move to restrict certain product integrations among chains by including such multiple-line chains within the chainstore tax laws while excluding single-line chains.

The first indication of a move to "go after" department stores was revealed in two rather mild-appearing laws enacted in 1897 , one in Indiana and one in Wisconsin. These laws ${ }^{12}$ merely contained statutory authorization to cities to license

\footnotetext{
${ }^{8}$ See note 3 , supra.

${ }^{\circ}$ See State v. Donaldson, $4 \mathrm{r}$ Minn. 74, 42 N. W. 78r (1889), which held invalid a provision of a pharmacy law restricting the sale of drugs and medicines to registered pharmacists. Since there was no exemption even for patent medicines, although the pharmacist was expressly exempted from liability for their quality, the court said such a complete prohibition was not designed to protect the public health but to create a monopoly in favor of the pharmacists. See, infra, the discussion of legislation restricting the retailing of drugs.

${ }^{10}$ See Paramount Pictures, Inc. v. Langer, 23 F. Supp. 890 (D. N. D. I938); S. H. Kress \& Co. v. Johnson, 16 F. Supp. 5 (D. Colo. 1936), aff'd per curiam, 299 U. S. 511 (1936); cf. Crescent Cotton Oil Co. v. Mississippi, 257 U. S. 129 (I92I) (integration in' production).

${ }^{11}$ See the long line of decisions originating with Powell v. Pennsylvania, 127 U. S. 678 ( 1888 ), through Lindsley v. Natural Carbonic Gas Co., 220 U. S. 6I (I9II); Price v. Illinois, 238 U. S. 446 (1915); Rast v. Van Deman \& Lewis Co., 240 U. S. 342 (I915); Standard Oil Co. v. City of Marysville, 279 U. S. 582 (1929); O'Gorman \& Young, Inc. v. Hartford Fire Ins. Co., 282 U. S. 25I (I93I); Nebbia v. New York, 291 U. S. 502 (1934); S. H. Kress \& Co. v. Johnson, supra nate ro.

${ }^{22}$ Ind. Laws, 1897 , c. 70; Wis. Laws, 1897 , c. 373.
} 
and regulate department stores, but such special authorization seems to indicate an attempt to empower municipalities to impose heavier exactions than could be justified under their general licensing or taxing powers. In neither of these states does there appear to have been any judicial test of these statutes.

A far more outspoken Missouri enactment ${ }^{13}$ of 1899 and a contemporaneous Chicago ordinance of like purport were, on the other hand, promptly held invalid. ${ }^{14}$ The state law divided merchandise into a certain number of classes which were rearranged into groups, and anyone employing more than 15 persons was prohibited from selling goods from more than one of the several classes or groups without paying a license fee of from $\$ 300$ to $\$ 500$ for each group, no fee being required for sales from only one group. The Chicago ordinance prohibited any meats, fish, butter, or other provisions from being sold "where dry goods, clothing, jewelry, and drugs are sold." Such laws were so obviously self-interest legislation procured by the small single-line merchants in an attempt to protect themselves against the development of the multiple-line department store, that the courts did not even attempt to find justification for them. ${ }^{15}$

Since the early r930's numerous bills have been introduced in state legislatures to prohibit public utilities from selling gas and electrical appliances to their customers. $^{10}$ However, only two have succeeded in enactment, one in Kansas and one in Oklahoma. ${ }^{17}$ The Oklahoma statute has not been litigated, but the Kansas law was promptly held invalid by the supreme court of the state. ${ }^{18}$ After determining that appliance sales are a natural incidence of a utility's power to sell and distribute

${ }^{23}$ See note 4, stipra.

${ }^{14}$ State ex rel. Wyatt v. Ashbrook, 154 Mo. 375, 55 S. W. 627 (1900); Chicago v. Nechter, 183 IIl. ro4, 55 N. E. 707 ( 1899 ). The authority claimed for the Chicago ordinance, which was obviously aimed at department stores, was the statutory power of the city to regulate the sale of meats and all other provisions. See, infra, note 65 and text for the provisions of this ordinance, likewise judicially condemned, prohibiting the sale of packaged liquors in such stores.

${ }^{15}$ In striking down the Missouri law, the court said: ". . . no reason has been given or suggested, and to our minds, none can be conceived why the arbitrary selection of persons . . . having . . . for sale, in the same store or building, under a unit of management or superintendency, at retail, . . . any articles or goods, ... of more than one of the several classifications or groups . . . designated, when 15 or more people are employed, was ... made, for the imposition of the license fee . . . from which all other persons and merchants of the State are exempted." State ex rel. Wyatt v. Ashbrook, supra note I4, at $395-396,55 \mathrm{~S}$. W. at 632 . Compare, the judicial attitude toward the so-called restaurant laws, discussed infra, and revealed in S. H. Kress \& Co. v. Johnson, supra note ro.

${ }^{16}$ Legis. (1937) 22 IowA L. REv. 736, 74I; Merchandising Electrical Appliances, A Report of the Electrical Merchandising Joint Committee (1933). The National Electrical Manufacturers Association, in a letter dated March 3, 194x, states that in the last four years, 1937-x940, 21 bills were introduced in various states, but none enacted, and that to date in $194 \mathrm{I}$ bills have been introduced in Connecticut and Massachusetts.

${ }^{27}$ Kan. Gen. Stat. (Corrick, I935) \$66-1210; OkLA. Stat. ANN. (1936) tit. 18, \$72. "It shall be unlawful for any public service corporation in this state, directly or indirectly, to engage in the sale of merchandise, utensils, or chattels of any sort not directly connected with the general business of such public service corporation as authorized by its charter, except as herein before provided. Nothing hercin shall be construed to prohibit any public service company from selling fuse plugs, electric light bulbs, outlet plugs, sockets, extension cords, or other repairs or equipment necessary to maintain continuity of service to any patron or patrons of such Company." Ibid.

${ }^{28}$ Capital Gas \& Electric Co. v. Boynton, 137 Kan. 717, 22 P. (2d) 958 (1933). 
gas, electricity and other public utility services, ${ }^{19}$ the court held that the statute "appears to be strictly class legislation without any reasonable relation to the welfare of the public." ${ }^{\prime 20}$ Proponents of the legislation attempted to argue that it was designed "to prevent a monopoly," and therefore justified as an exercise of the police power in the interests of the general welfare of the public. The Kansas court decided, however, that the effect of the law was to create a monopoly rather than to prevent one. "The obvious result of the enactment . . . would be to limit the sale of such appliances to merchants and others. ..." With no feature of public interest therefore involved, to single out the utilities as a class and forbid them to merchandise appliances was held to deny them arbitrarily the equal protection of the laws. It should be noted that this decision was rendered in spite of the fact that the evidence showed the utility companies sold from 80 to 90 percent of the gas appliances in the communities where they operated and in connection with such sales performed certain functions and rendered certain services ${ }^{21}$ which only their size and position as a utility permitted them to do, and which, therefore, the regular appliance dealers complained they could not match. ${ }^{22}$

So here we have the legal seal of approval placed upon two developments of multiple-line organization, whereas other attempts at integration of so-called unrelated lines have been condemned as productive of monopolistic power. Such condemnation was achieved through application of the general language of the Sherman Act to the activities of the great meat-packing companies of the country, Swift, Armour, Morris, and Cudahy. A consent decree was entered against these companies in $1920{ }^{23}$ by the terms of which a monopolistic combination of the companies was dissolved and the units that composed it were individually enjoined, among

${ }^{10}$ The courts of the country are almost universally in accord with this view: Hamler v. City of Jacksonville, 97 Fla. 807, 122 So. 220 (x929); Holten v. City of Camilla, 134 Ga. 560, 68 S. E. 472 (19ro); Andrews v. City of South Haven, I87 Mich. 294, I53 N. W. 827 (1915); Milligan v. Miles City, 5 I Mont. 374, I53 Pac. 276 (1915); Malone v. Lancaster Gas Light \& Fuel Co., I82 Pa. 309, 37 Atl. 932 (1897); Commonwealth ex rel. Baldridge, Atty. Gen. v. Philadelphia Electric Co., 300 Pa. 577, I51 Atl. 344 (1930); Erie Lighting Co. et al. v. Penn. Public Utility Comm., II3 Pa. Super. 190, 198 Atl. 901 (1938).

${ }^{20}$ Capital Gas \& Electric Co. v. Boynton, supra note 18 , at 729, 22 P. (2d) at 964.

${ }^{21}$ Such as (I) liberal allowances for used appliances which bore no exact relation to the value thereof; (2) free servicing of the appliances; and (3) charging up the loss in the operation of the appliance department as an operating expense of the company so that it became a factor in its utility rate structure. Capital Gas \& Electric Co: v. Boynton, supra note 18, at 723-724, 22 P. (2d) at 96r. See also Andrews v. City of South Haven, supra note 19; Keen v. City of Waycross, Ior Ga. 588, 29 S. E. 42 ( 1897 ). Pennsylvania attempted to remedy this situation in 1937 by enacting a law which, instead of prohibiting utilities from selling appliances, regulates certain practices in connection with such sales. PA. St八t. ANN. (Purdon, Supp. 1940) tit. 66, $\$ 1352$, prohibiting the utility from discontinuing utility service to a consumer for failure to pay for appliances, forbidding it to apply to the purchase price thereof any consumer deposit, and requiring separate accounts concerning its appliance sales. Several other states also require the keeping of separate accounts. ILL. Rev. STrr. (Smith-Hurd, 1939) c. $\operatorname{Irr} 2 / 3$, \$12; S. C. CODE (Supp. 1934) \$8555-2(16); Wastr. Rev. Stat. ANN. (Remington, Supp. 1939) §10458-2; Wis. Rev. STrT. (1939) \$196.59.

${ }_{22}$ Contrast the judicial attitude displayed in Paramount Pictures, Inc. v. Langer, supra note Io.

${ }^{23}$ The decree was entered in 1920 in the Supreme Court of the District of Columbia, sitting in equity. 
other things, from continuing to trade, either at wholesale or retail, in so-called groceries, i.e. in certain unrelated foodstuffs not within the scope of the meat-packing industry. ${ }^{24}$

The reasons maintained by the government for the prohibitions of this decree were twofold. The first was that through the ownership of refrigerator cars and branch houses as well as other facilities, the companies were in a position to distribute these foods and other unrelated commodities with substantially no increase in overhead. Secondly, that they fixed prices for groceries so low over temporary periods of time that the competition of less favorably situated rivals was eliminated and they were enabled to establish a monopoly of a large part of the food supply of the nation. ${ }^{25}$

In the two cases involving this decree which reached the Supreme Court of the United States, ${ }^{26}$ the Court refused to disturb it, thus leaving in effect the requirement for divorcement of lines. It is important to note here that the decree prohibited the individual companies from engaging in such unrelated lines of business, "upon the theory that even after the combination among the packers had been broken up and the monopoly dissolved, the individual units would be so large that the capacity to engage in other forms of business as adjuncts to the sale of meats should be taken from them altogether."27 Here, then, we have the Sherman Act being used, with the specific recognition of the Court, to protect an established class of business, the wholesale grocers and produce dealers. ${ }^{28}$

However, it is arguable whether either one of the Swift cases is necessarily persuasive of the point that the language of the Sherman Act can be used to prohibit such product integration. In neither case was the Court passing directly upon the

\footnotetext{
${ }^{24}$ More specifically, it enjoined the defendants, without consent of the court, (I) from engaging or being interested in the business of manufacturing, buying, selling or handling any one of 114 enumerated food products or any one of 30 other named articles of commerce; (2) from selling milk or cream; (3) from selling meat at retail; and (4) from using their distributive systems (including branch houses, refrigerator cars, route cars, and auto trucks) in any manner for the purpose of handling any of the many articles referred to. For other aspects of this decree, see the discussion, infra, of restrictions on vertical forms of integration.

${ }^{25}$ See United States v. Swift \& Co., 286 U. S. 106 (1932). Compare this with the attitude expressed in Capital Gas \& Electric Co. v. Boynton, supra note 18, in which the Kansas high court invalidated the prohibition on the marketing of appliances by public utilities, in spite of the fact that the very reasons for which the regular retail dealers sponsored the law were bottomed on what they claimed were the unfair competitive advantages which the size of the utilities gave them in such merchandising. See Nelson-Johnston \& Dowdna v. Metropolitan Utilities Dist., 29x N. W. 558 (Neb. 1940). Added to such competitive advantages there was the objection, not present in the meat packing casc, that the utilities engage in appliance sales not for their own sake, but merely as a means to load-building, and therefore can afford to operate their appliance departments at a loss by absorbing such loss in their utility business. See (Mar. II, I939) III Electrical World 689; Capital Gas \& Electric Co. v. Boynton, supra note 18 .

${ }^{20}$ Swift \& Co, v. United States, 276 U. S. 31 I (1928); United States v. Swift \& Co., supra note 25.

${ }^{27}$ United States v. Swift \& Co., stupra note 25 , at 116.

28 "The question is . . . whether a modification as to groceries can be made [in the decree] without prejudice to the interests of the classes whom this particular restraint was intended to protect . . wholesale grocers." United States v. Swift \& Co., supra note 25 , at II7, 118 . It should be noted here, of course, that the law has today established that the fact a statute is passed primarily in the interests of a class, will not of itself render such statute invalid. Nebbia v. New York, supra note II; Borden's Farm Products Co. v. Ten Eyck, 297 U. S. 25 I (1936); Paramount Pictures, Inc. v. Langer, stupra note ro.
} 
correctness of the inclusion within the consent decree of such a prohibition. The I928 case came up on a motion of Swift and Armour to vacate the decree and declare it void. Consequently, said the Court, the question was merely whether the original court had the power to render such a decree at all. This question it answered affirmatively and then went on to say that the defendants, by consenting to the entry of the decree, had waived any error in decision. ${ }^{29}$

The 1932 case came before the Court in an effort of Swift and Armour to secure a modification of the consent decree to permit the wholesaling of groceries. In refusing to disturb the decree, the Court emphasized that the question was not one of reviewing the decree to determine whether it was right or wrong originally, but whether, having been made to include the collateral lines of trade with the consent of each defendant, it should now be relaxed because of changed conditions. In determining that sufficiently changed conditions did not exist, the Court said: ${ }^{30}$

We do not turn aside to inquire whether some of these restraints upon separate as distinguished from joint action could have been opposed with success if the defendants had offered opposition. Instead, they chose to consent, and the injunction, right or wrong, became the judgment of the Court.

Closely akin to the anti-department store laws are the recent "restaurant" laws enacted by Colorado and Wisconsin. ${ }^{31}$ Obviously designed to protect the restaurant from the competition of meals served by drugstores and five-and-tens, they achieve this by prohibiting a restaurant from being operated in the same room with any other business. But this time the judicial seal of approval was placed upon the restriction and not upon the new form of distribution. ${ }^{32}$ The Colorado law was construed, in two request opinions of the Colorado Supreme Court, ${ }^{33}$ as not prohibiting anyone engaged in another business from also engaging in the restaurant business, but as merely requiring, if he wishes to be both merchant and restaurateur, that he conduct the businesses in separate rooms. It further held that physical connections between such rooms, such as connecting doors, were permissible. ${ }^{34}$

20 ". . . had the defendants not waived such error by their consent, they might have had it corrected upon appeal." Swift \& Co. v. United States, supra note 26 , at 331 .

${ }^{80}$ United States v. Swift \& Co., supra noto 25 , at 116 , 117 .

${ }^{31}$ Colo. Stat. ANN. (Michie, r935) c. 8I, \$\$13-24; WIs. Cone (I939) \$\$I60.oI-I60.08. Three similar bills were introduced in the New York legislature in 1940 but were not enacted. Furthermore, a bill has been introduced in the present session of the South Dakota legislature, H. B. No. 122 (194r), which would impose a \$ro license tax on separate grocery and butcher shops, a $\$ 1,000$ license tax on combined grocery and meat stores.

${ }^{32} \mathrm{~S}$. H. Kress \& $\mathrm{Co}_{4}$ v. Johnson, stupra note to.

${ }^{83}$ In te Interrogatories of the Governor, 97 Colo. 587, 52 P. (2d) 663 (1935), rendered at the request of the Governor of Colorado, defendant in a suit by Kress \& Co. and others, to restrain enforcement of the law. S. H. Kress \& Co. v. Johnson, supra note Io.

36 It should be noted that the Wisconsin law in specific terms provided that a restaurant could be conducted on the same premises as other businesses if separated therefrom by ceiling-high partitions and self-closing doors. The Colorado law, however, provided: ". . . it shall be unlawful . . . to sell ... 'food' for consumption on the premises except . . . in a licensed 'restaurant,' as defined. . . . 'Restaurant' shall mean an establishment ... whose principal business is the sale of meals, and in which room nothing is sold excepting meals, food, drink and tobaccos. Any establishment connected with any business whatsoever ... wherein any business is conducted excepting the sale of meals, ... is hereby declared not to be a restaurant." 
Adopting this interpretation of the Colorado law as conclusive and framing the issue after the manner of current judicial technique in such cases, ${ }^{35}$ the federal district court, in a decision subsequently affirmed per curiam by the United States Supreme Court, succeeded in justifying the measure as one reasonably designed to protect the public health. ${ }^{38}$

In doing so, the court held that against the constitutional argument of lack of due process the presumption of constitutionality must prevail in favor of a statute allegedly enacted in the protection of some public interest, here the public health, even where there is a sharp conflict of opinion among experts in the field as to whether it will tend to protect such public interest, if there is some substantial evidence to support the view that it will. "It is plainly not enough that the subject should be regarded as debatable. If it be debatable, the legislature is entitled to its own judgment. ..."37 This test of reasonableness is to be compared with that enunciated in $O^{\prime}$ Gorman \& Young, Inc. v. Hartford Fire Ins. $\mathrm{Co}_{0}{ }^{\mathrm{s}}$ in which the Court held that the presumption of constitutionality must prevail in favor of a statute allegedly enacted under the police power, when "the record is barren of any allegation of fact tending to show unreasonableness."30

However, the apparent liberality of these rules in testing the constitutionality of non-integration legislation, is limited by several factors. In the first place, in both the Kress and O'Gorman cases the Court was assisted by the fact that the statute on its face dealt with a general subject previously established as within the power of the state to regulate. ${ }^{40}$ Since the end, or policy, declared by the statute in each case was lawful on its face, the question was therefore stated to be, merely whether the specific means provided were "reasonably" adapted to achieve this lawful end.11

Hence if a non-integration statute does not on its face deal with a subject which a court can recognize as having been established as within the police power, wit-

${ }^{35}$ See text and notes ro and II, supra.

${ }^{36} \mathrm{~S}$. H. Kress \& Co. v. Johnson, supra note ro. In affirming the decision of the district court, the United States Supreme Court wrote no opinion, but merely cited as authority for its action, Powell v. Pennsylvania, I27 U. S. 678 (1888) (upholding oleomargarine tax law); Price v. Illinois, 238 U. S. 446 (1915) (upholding prohibition on food preservative containing boric acid); Standard Oil Co. v. City of Marysville, 279 U. S. 582 (1929) (upholding ordinance prohibiting storage of gasoline above ground); (4) Nebbia v. New York, 29I U. S. 502 (1934) (upholding minimum price fixing of milk).

${ }^{37} \mathrm{~S}$. H. Kress \& Co. v. Johnson, stipra note 10, at 8 . See also Rast v. Van Deman \& Lewis Co., supro note $x x$, for an application of the same test in 1915 in the Trading Stamp case.

${ }^{38}$ Supra note $\mathrm{XI}$.

${ }^{38} \mathrm{Id}$. at 258 ; ". . . the presumption of constitutionality must prevail in the absence of some factual foundation of record for overthrowing the statute. It does not appear upon the face of the statute, or from any facts of which the court must take judicial notice, that ... cvils did not exist . . . for which this statutory provision was an appropriate remedy." Id. at $257,258$.

${ }^{40}$ In the Kress case, with the regulation of the serving of food by restaurants in the interests of the public health; in the O'Gorman case, with the regulation of the rates of insurance companies in the interest of public welfare, see German Alliance Insurance Co. v. Lewis, 233 U. S. 389, 412 (1913).

${ }^{1} \mathrm{~S}$. H. Kress \& Co. v. Johnson, supre note 10 , at 7 , the means in this case being the requirement that a restaurant be conducted in a separate room from any other business; O'Gorman \& Young, Inc. v. Hartford Fire Ins. Co., supra note Ir, at 257, the means here being the requirement that no fire insurance company could allow a commission to any person acting as its local agent respecting such insurance, in excess of that allowed to any of its local agents on such risks in the state. 
ness the anti-department store laws ${ }^{42}$ and the public utility anti-merchandising laws, ${ }^{43}$ it must do more than apply one of the tests enunciated in the O'Gorman and Kress cases. In addition to deciding the question of means, a court must first decide the question of legislative power, or in other words, whether the end sought is within the jurisdiction of the legislature as an exercise of the police power. ${ }^{44}$

Another possible limitation to the liberal application of the test in the Kress case is the fact that the federal district court, despite its statements that it is not within the province of the judiciary to disturb a legislative finding if there is evidence to support it, even where "the evidence leaves the question . . . fairly debatable," itself regarded the restriction as one likely to preserve the public health. ${ }^{45}$

Then again, a non-integration statute might be struck down as offending the equal protection clause. Although courts are extremely liberal in determining the question of reasonable classification, ${ }^{46}$ the classification set-up to protect the special interest may be so arbitrary that a court will be unable to find any relation to the public health. This was the situation in the early Illinois decision ${ }^{47}$ invalidating the Chicago anti-department store ordinance to which previous reference has been made. Although the ordinance purported to deal with a subject within the scope of the police power, the regulation of food in the protection of the public health, it did not require meat and other provisions to be sold only by meat and provision stores, and did not prohibit all merchandise dealers from selling meat and provisions. Rather, it merely singled out those carrying certain lines of commodities, in other words, department stores. The distinction was therefore arbitrary, in the opinion of the Illinois court. A further instance of similar judicial reaction is to be found, it will be recalled, in the case invalidating the Kansas anti-utility merchandising act. ${ }^{48}$

Three states, Ohio, New Hampshire and Vermont, ${ }^{49}$ have laws which can be construed to prohibit motor vehicle dealers from combining any other line of business with that of the sale of motor vehicles. The Ohio provision is the most conclusive in that it would seem specifically to prohibit such integration by providing

${ }^{12}$ See discussion and notes 14 and 15 , supra.

${ }^{13}$ See discussion and notes 17,18 and 20 , supra.

"See notes 40 and $4 \mathrm{~T}$, supra. It should be noted here, however, that the court was required to answer both questions in Paramount Pictures, Inc. v. Langer, stupra note ro, in determining the validity of a law prohibiting motion picture producers and distributors from owning or operating motion picture theaters in the state, and answered them both affirmatively. See discussion and note II 8 , infra. Compare, however, the decisions concerning the anti-department store and anti-utility merchandising laws.

${ }^{4} \mathrm{~S}$. H. Kress \& Co. v. Johnson, supra note ro, at 7,8 .

10... . it is established that a distinction in legislation is not arbitrary, if any state of facts reasonably can be conceived that would sustain it, and the existence of that state of facts at the time the law was enacted must be assumed." Rast v. Van Deman \& Lewis Co., supra note II, at 357; Lindsley v. Natural Carbonic Gas Co., supra note II. Followed in S. H. Kress \& Co. v. Johnson, supra note ro, at 9 .

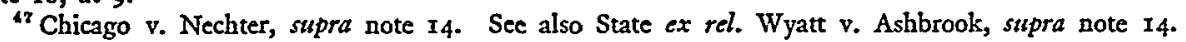

${ }^{48}$ Capital Gas \& Electric Co. v. Boynton, supra note 18.

"D Omo Gen. Code (Baldwin's Throckmorton, 1940) $\$ \$ 6302-1$ to $6302-3$; N. H. Laws 1939, c. 47, amending N. H. Pus. LAws (1926) c. 99, \$1, I4; Vt. Laws 1937, act 1r3, amending Vt. REv. PuB. Laws (I933) $\$ 4986$. 
that licenses required of all dealers will be denied to any dealer who does not have an "established place of business which is used ... solely and exclusively for ... dealing in motor vehicles." ${ }^{\text {"50 }}$ Such prohibition is further supported by a definition of the term "dealer" as meaning "all persons ... regularly engaged in the business of selling ... motor vehicles at an established place of business which is used solely and exclusively for ... selling ... motor vehicles." ${ }^{\text {.51 }}$ The only exemption from the prohibition is the maintenance, in connection with such establishment, of repair, accessory, gasoline and oil, storage, parts, service or paint departments, if operated "for the purpose of furthering and assisting in the business of selling . . . motor vehicles."

Although the New Hampshire and Vermont statutes ${ }^{53}$ define the term motor vehicle "dealer" in language almost identical with that of Ohio, ${ }^{54}$ such definitions are not part of, or applicable to, any law requiring the licensing of such dealers. Instead, they are part of the regular motor vehicle law and seem to be included primarily for purposes of the provisions concerning the issuance of dealers' registration plates. As a part of such law, however, the definition necessarily limits the issuance of special dealer plates to those dealers who maintain a place of business devoted exclusively to the motor vehicle business. Whether the limitation in connection with such registration-plate provision would successfully operate to keep motor vehicle dealers from engaging in any other line of business remains an open question, for neither of these provisions, nor the Ohio prohibition, has yet been litigated. However, assuming that they were construed so to operate, and certainly the Ohio provision is mandatory, it is difficult to see how the courts could find any aspect of the public health, safety, morals or general welfare sufficiently present to sustain them.

In the field of alcoholic beverages, eleven states, ${ }^{55}$ not taking into consideration those operating a state monopoly, provide some form of legislative restriction on the package retailing of such beverages in connection with other lines of business. Indiana and Rhode Island limit the sale of "hard" liquors by the package to drug and exclusively liquor stores; ${ }^{56}$ New Hampshire and certain counties of Maryland, to drug and grocery stores; ${ }^{57}$ Missouri to drug, grocery, tobacco, delicatessen and general merchandise stores; ${ }^{58} \mathrm{New}$ York to exclusive liquor stores, permitting beer to be retailed only by drug and grocery stores; ${ }^{59}$ while New Jersey authorizes her

${ }^{\circ 0}$ OHo Gen. CODE (Baldwin's Throckmorton, I940) \$6302-3.

51 Id. $\$ 6302-\mathrm{I}$. $\quad{ }_{52} I d$. $\$ 6302-3$. $\quad$ cited stipra note 49.

${ }^{\circ}$ N. H.: "Dealer: every person ... in the business of . . . selling . . . motor vehicles ... who maintains a place of business devoted exclussively to the motor vehicle business. . . ." Vt.: "Dcaler: ... a person actively engaged in ... the business of . . . selling . . . motor vehicles . . . who maintains a salesroom or garage devoted exclusively to the motor vehicle business. ..."

${ }^{65}$ Ind., Md., Mich., Minn., Mo., N. H., N. J., N. Y., Ohio, Pa., R. I.

${ }^{50}$ IND. Stat. ANN. (Burns, Supp. 1940) \$12-518; R. I. Laws 1933, c. 2013, \$5B, as amended by

R. I. Laws 1936, c. $2338, \S \mathrm{r}$.

${ }_{\text {in }}$ N. H. Laws 1933, c. 99, \$9; MD. CodE ANN. (Flack, 1939) art. 2B, \$\$6, 30.

${ }^{68}$ Mo. STAT. ANN. (Supp. 1940) $\$ 4525 g-26$.

to N. Y. Alcoholic Beverage Control LAw $\$ \$ 54(4), 63(4), 79$. 
cities to limit such sales to exclusively liquor stores. ${ }^{60}$ Pennsylvania, which operates a state monopoly system for the retailing of "hard" liquors and wines, permits the retailing of malt beverages by private business concerns, but in so doing limits such sales to hotels and restaurants. ${ }^{61}$

Although there is little judicial authority on the constitutionality of such restrictive provisions as applied to alcoholic beverages, what does exist is almost wholly favorable. ${ }^{62}$ As recently as 1937 , the Supreme Court of Illinois upheld an ordinance prohibiting retail grocery stores and meat markets from selling malt beverages in bottles or sealed containers "for consumption on the premises." 33 In doing so, the Illinois court declared that prohibiting such integration of lines only to grocery and meat stores and not to business concerns marketing other types of commodities, does not create such an arbitrary classification as to render the provision unconstitutional. The purchase of meats and food products being almost a daily necessity, it may be to the good of the city, reasoned the court, to guard women and children from close contact with the sale of alcoholic beverages: ${ }^{64}$

While we might differ with the views of the city council as to any injurious results traceable to the sale of malt liquor . . . in the designated class of dealers, it . . . is not within our province to substitute our views for those of the legislative department. ...

It should be noted that the prohibition involved in this case was against sales for consumption on the premises, and not package sales for off-premise consumption. It was on this basis that the court attempted to distinguish the case from the early decision of Chicago v. Nechter ${ }^{65}$ which invalidated as discriminatory an ordinance prohibiting intoxicating liquors from being sold by the package in any place of business retailing "dry goods, clothing, jewelry or hardware."

However, such a restriction as applied to package sales was upheld as recently as 1935 , in a case $\mathrm{e}^{66}$ which declared valid an ordinance prohibiting retail liquor dealers from engaging in the mercantile or drug business in the same building in which they operated their liquor business. ${ }^{67}$

It is apparent that the owner of the two businesses so located may take advantage of this condition to increase the sales of intoxicating liquors to the public in ways ... he could not employ if the businesses were otherwise located . . . and while it is possible that the ordinance . . . may not be based on the soundest sort of wisdom and reason, yet it has sufficient foundation to make it a matter within the scope of legislative authority.

${ }^{00}$ N. J. STAT. ANN. (1940) \$33:1-12.

${ }^{0 I}$ P.. Stat. ANN. (Purdon, Supp. 1940) tit. 47, \$744-412.

${ }^{02}$ Great A. \& P. Tea Co. v. Mayor of Danville, 367 Ill. 310, II N. E. (2d) 388 (1937); Tittsworth v. Akin, II8 Fla. 454, 159 So. 779 (1935); Sloan v. Hutchingson, I20 Fla. 747, I63 So. 6I (1935); Peer v. Board of Excise, 70 N. J. L. 496, 57 Atl. 153 (1904); Jacobs Pharmacy Co. v. City of Atlanta, 88 Fed. 244 (C. C. N. D. Ga., I898).

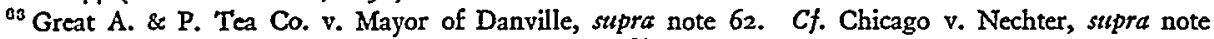
14, and discussion of anti-department store laws. ${ }^{84} I d$. at 3 I8, II N. E. (2d) at 392.

${ }^{25}$ Stupra note I4. See, also, the discussion of this case in connection with the anti-department store laws, supra.

${ }^{80}$ Tittsworth v. Akin, supra note 62. ${ }^{87} 7 d$. at 463 , I59 So. at 782 . 
An $r 898$ federal case $e^{68}$ upheld an ordinance prohibiting the sale of liquors by drug stores. Finally, in Peer v. Board of Excise ${ }^{69}$ the validity of a restriction of this type was apparently assumed, when the New Jersey court held that the issuance to a grocery store of a retail liquor license was a violation of a statute prohibiting such licenses to stores in which a grocery or other mercantile business is carried on.$^{70}$

The field of drugs perhaps boasts the longest history of legislation prohibiting distribution of a certain line of products by those engaged in other lines of business. It is well known that all states, as a public health measure, regulate in some manner the sale of drugs, medicines and poisons. Among other regulatory provisions, nearly all states restrict the sale of such commodities to registered pharmacists. The ostensible justification for such a restriction is, of course, the protection of the public health on the theory that the retailing of drugs and similar products should be limited to those specially trained and skilled in the subject of pharmacy and drugs. ${ }^{71}$ Such an absolute restriction is certainly justified in connection with the compounding of prescriptions. But what of the hundreds of drugs which are today so standardized that they are merely sold over the counter in the manufacturer's original package as any ordinary piece of merchandise? ${ }^{72}$ Add to this the fact that nearly all state pharmacy laws exempt from their terms the sale of so-called patent or proprietary medicines and sometimes what are designated as ordinary household remedies, and there seems to be no justification on the ground of public health for prohibiting merchants other than pharmacists from selling standardized products in the original package of the manufacturer. ${ }^{73}$ This conclusion seems even more necessary when consideration is given to the fact that many of the pharmacy laws provide that a pharmacist shall not be held responsible for the quality of drugs sold in the original package. ${ }^{74}$ Furthermore, even though the pharmacy law itself may contain no such provision, nearly all state pure food and drug laws carry the usual clause exempting dealers from liability when they can establish a written guaranty from the manufacturer or distributor. ${ }^{75}$

These facts are perhaps best illustrated by the recent history of the Montana pharmacy act, which prior to 1939 contained a provision ${ }^{76}$ limiting to registered pharmacists the retail sale of all drugs and medicines except patent or proprietary medicines in the original package, when plainly labeled. The Montana Supreme

${ }^{88}$ Jacobs Pharmacy Co. v. City of Atlanta, supra note 62.

${ }^{69}$ Supra note 62.

${ }^{70}$ See, also, Sloan v. Hutchingson, supra note 62 , for a dictum supporting the legality of such nonintegration measures.

${ }^{71}$ See State v. Stephens, 102 Mont. 414, 59 P. (2d) 54 (1936); Kentucky Bd. of Pharmacy v Cassidy, II5 Ky. 690, 74 S. W. 730 (I903).

${ }^{7}$ See, Kentucky Bd. of Pharmacy v. Cassidy, supra note 71, at 706, 74 S. W. at 734: "It requires no more scientific skill to do so than to sell soap or perfumery, or any other like articles. . . ."

${ }^{73}$ See State v. Stephens, Kentucky Bd. of Pharmacy v. Cassidy, both supra note 71; Arizona v. Childs, 32 Ariz. 222, 257 Pac. 366, 54 A. L. R. 736 (1927); State v. Donaldson, supra note 9.

"E.g., Ariz. Code ANn. (1939) \$67-1518; N. M. Stat. Ans. (Courtright, 1929 and Supp. 1938) \$103-108; N. C. CoDE (Michie, 1939) \$6665.

${ }^{75}$ See, Orla. Stat. ANN. (1936) tit. 63, \$260; PA. Stat. ANN. (Purdon, Supp. 1940) tit. 35, \$79x. Other states with similar provisions are R. I., S. C., Va., Wyo.

${ }^{70}$ MoNT. Rev. Codes (Anderson \& McFarland, I935) $\$ 3170,318 \mathrm{r}, 3184$. 
Court held this provision to be unconstitutional because it prevented a grocer from selling aspirin. ${ }^{77}$ Such a prohibition, declared that court, does not appear to preserve the public health in any way since no act of skill or special knowledge is involved in the sale of a standard article like aspirin. Moreover, the pharmacy law itself contained a provision absolving the pharmacist from responsibility for the quality of drugs when sold in the original packages of the manufacturer. ${ }^{78}$ Therefore, reasoned the court, there is no justification for restricting the sale of such articles to registered pharmacists only. ${ }^{79}$ Another court, invalidating a similar provision, said:"0 "It would be giving pharmacists a monopoly of the business, without in any manner protecting the public health."

Some 2I states ${ }^{81}$ contain provisions in their pharmacy laws which operate to prohibit the sale of aspirin by other than registered pharmacists. The same is true of many standard medicines, for few states exempt from the registered pharmacist restriction any articles other than patent or proprietary medicines and a rather standardized list of common household remedies such as alum, aromatic spirits of ammonia, bay rum, bicarbonate of soda, epsom salts, castor oil, glycerine, essence of peppermint, peroxide of hydrogen, witch-hazel and similar products. ${ }^{\mathbf{8 2}}$

In the field of chain merchandising are to be found certain forms of horizontal or product integration that are restricted or penalized without an equivalent burden being placed upon either single-line chains or independent stores. This discrimination is effected by exempting from the chain-store tax laws certain product chains only if the sale of such product constitutes the chain's exclusive, or in some instances, principal, business. The best known of such exemptions is that granted to pure filling stations, i.e. stations selling gasoline exclusively. ${ }^{83}$ Such a provision necessarily penalizes those stations which also deal largely in accessories while not placing a similar

${ }^{\pi 7}$ State v. Stephens, supra note $7 \mathrm{I}$.

${ }^{78}$ MONT. Rev. Codes (Anderson \& McFarland, r935) $\$ 3 r 84$.

70 Accord: Kentucky Bd. of Pharmacy v. Cassidy, supra note 71; Arizona v. Childs, State v. Donaldson, both supra note 73. Montana amended its pharmacy law in 1939 to permit the sale of drugs "prepared in sealed packages or bottles by a manufacturer, qualified under the laws of the state where the manufacturer resides." MoNr. Rev. Codes (Anderson \& Wertz, Supp. r939) \$3177.x. Query, as to whether the use of the term "sealed" would limit the effectiveness of this exemption. Furthermore, it should be noted that Montana repealed the section absolving the dealer from responsibility for the quality of drugs sold in the manufacturer's original packages. The new section regulating the quality of drugs now provides merely that nothing in the state pure food and drug act shall be changed by the pharmacy law. Id. \$3187.3. The pure food law contains the usual exemption clause for dealers establishing written guaranties. MONT. REv. CoDEs (Anderson \& McFarland, I935) \$2588.

${ }^{80}$ State v. Donaldson, supra note 9 , at $83,42 \mathrm{~N}$. W. at 783 .

${ }^{81}$ Ariz., Calif., Colo., Ill., Ind., Iowa, Mass., Mich., Minn., Mo., Nev., N. H., N. J., N. M., N. Y., N. C., N. D., Ohio, S. D., Wis., Wyo.

${ }^{89}$ See Ariz. Code Ann. (1939) \$\$67-1506, 67-1513, 67-1514; Ore. Comp. Laws Ann. (1940) $\$ \$ 58-103,58-107 ;$ N. C. CoDE (Michie, r939) \$6667.

${ }^{83}$ Fla., Idaho and Minn. exempt pure filling stations. Fla. Comp. Gen. Laws (Skillman, Supp. 1936) \$415 (95b); Idaho Laws 1933, c. II3, \$7; MinN. Stat. (Mason, Supp. 1940) \$5887-18b. Ga., Md., Mich. and Miss. exempt dealers whose "principal business" is the sale of gasoline or petroleum products. Ga. Code ANn. (Park, et al., 1936) \$92-1602; MD. ANn. Code (Flack, 1939) art. 56, \$65; Mích. Stat. AnN. (Henderson, 1936) \$7.482; Mrss. Code ANN. (Supp. 1938) \$774. Texas exempts stores selling and distributing petroleum products and servicing motor vehicles. Tex. Laws Ist Ex. Sess. 1935, c. 400,95 . 
burden upon independent tire and battery stores. There is also the exemption found in the Iowa chain-store tax law ${ }^{84}$ which is granted to retailers of coal, ice, lumber, grain, feed and building material provided 95 percent of their total receipts derive from sales of one or more of those products. With only minor variations, Minnesota and South Dakota provide exemption clauses almost identical with that of Iowa. ${ }^{85}$ Whatever the purpose in the enactment of these exemption clauses, it is clear that one of their effects is to favor non-integration of products when the business is done on a chain basis. ${ }^{86}$

\section{Vertical Integration of Distributing Units}

Not only have the legislatures been active in prohibiting and restricting forms of horizontal integration among distributors; activity on behalf of the old-line merchant has extended to prohibition of the vertical integration of the distributing units themselves. Such legislative restrictions are most evident in the field of alcoholic beverages, 32 states prohibiting wholesalers of such beverages from engaging in retail sale. ${ }^{87}$ With the exception of ro of these laws, four of which contain only minor exceptions, ${ }^{88}$ and six others the statutory language of which might possibly be construed otherwise, ${ }^{89}$ the prohibition is absolute.

Another wholesaler-retailer non-integration statute is found in the California law $^{90}$ which prohibits wholesalers of frames, lenses, optical supplies, optometric appliances or devices and kindred products from engaging in the retail business of filling prescriptions of physicians and surgeons for ophthalmic lenses and kindred products. To the writers' knowledge, this statute has not been tested in the courts.

Finally, it is interesting to note that in the meat-packing cases ${ }^{91}$ already discussed, the general prohibitions of the Sherman Act were used not only to prohibit the combination of unrelated lines of groceries with that of meats, but also to prohibit such companies from engaging in the retailing of meats. ${ }^{22}$ In the second Swift case, ${ }^{03}$ the two companies, Swift and Armour, asked that the consent decree be modified

84 IOWA CODE (1939) \$6943.128.

${ }^{80}$ MINN. StAT. (Mason, Supp. I940) $\$ 5887-18 \mathrm{~b}$ (fuel, lumber, building material, gasoline and oils and grains); S. D. CODE ( 1939 ) $\$ 57.3403$ (same as Minnesota plus dairy products, poultry, electric current, natural or artificial gas, and telephone service). See also Tex. Laws Ist Ex. Sess. 1935, c. 400, $\$ 5$ (exempts those dealing exclusively in lumber and building matcrials).

${ }^{80}$ Compare this legislation directed at horizontal chain integration with the discussion, infra, of prohibitions on vertical chain integration contained in the Patman Bill to divorce chain retailing from manufacturing. See Stevens, Chain Store Taxation (1940) 33 Proc. Nat. Tax Ass'n I70 for criticism of the original Patman federal chain-store tax proposal for its failure to exempt accessory-selling as well as pure filling stations. Stevens clearly views such legislation as presenting the economic issue of the validity of penalization of horizontal integration.

${ }^{87}$ Ala., Ark., Calif., Colo., Conn., Fla., Ill., Ind., Iowa, Kan., Me., Mich., Minn., Miss., Mo., Mont, N. H., N. J., N. M., N. Y., N. D., Ohio, Ore., R. I., S. D., Tenn., Tex., Vt., Va., Wash., W. Va., Wyo.

${ }^{88}$ Ill., Ind., Mont., N. H., permitting retail sales at the wholesale premises only, or limiting the wholesaler to one retail license.

${ }^{80}$ Me., Mich., Miss., N. M., Ohio, Tenn. E.g. OHo Code ANn. (Baldwin's Throckmorton, 1940) $\$ 6-64-24$ : "No wholesaler shall have any interest in the business of any retail dealer."

${ }^{\circ 0}$ Calif. Bus. \& Prof. Code (Deering, Supp. 1939) \$2553.5.

${ }^{21}$ See notes 25 and 26 , supra.

${ }^{02}$ See note 24 , stspra.

${ }^{93}$ United States v. Swift \& Co., supra note 25. 
to permit not only the wholesaling of groceries, but also the operation of retail meat markets. Although the Supreme Court of the District of Columbia, in which the petition for such modification was filed, permitted modification to allow the wholesaling of groceries, a decision subsequently reversed by the United States Supreme Court, ${ }^{94}$ it refused to permit the retail sale of meats, a refusal affirmed by the high Court." As this Court said, "The one prohibition equally with the other was directed against abuse of power by the individual units after the monopoly was over. ... ."96

\section{Vertical Integration of Production and Distribution}

The legislative weapon has also been used to divorce production from distribution in certain fields by prohibiting the integration of the function of production with that of distribution. The greatest activity in this line is again to be found in the field of alcoholic beverages. No less than $3^{6}$ states to some extent prohibit manufacturers of one or more types of such beverages from engaging in the retail sale thereof, ${ }^{97}$ while $\mathrm{I} 3$ states also prohibit them from engaging in the wholesale business. $^{98}$ Twenty-two of the states which prohibit retailing by manufacturers make the prohibition an absolute one, ${ }^{99}$ while of the remaining laws, five contain only minor exceptions, such as permitting the manufacturer to retail his own products from his manufacturing premises only, ${ }^{100}$ and nine contain language which, although not as clear-cut as in the other 22 states, could be construed as prohibiting such integration. ${ }^{101}$ Such a complete prohibition is but an extension of the provision of the Federal Alcohol Administration $\mathrm{Act}^{102}$ prohibiting manufacturers from holding an interest in retail establishments if it has the effect of inducing the retailer to purchase the products of the vendor to the exclusion in whole or in part of competing products. ${ }^{103}$ This limitation, which discloses the original purpose behind the enactment, is found in only one of the state laws prohibiting manufacturer ownership and control of retail establishments. ${ }^{104}$

${ }^{0}$ Ibid. ${ }^{95}$ Ibid.

${ }^{01}$ Id. at II7. For the reasons for this separation of functions, see the discussion of the Switt cases under product-integration, supra.

${ }^{07}$ The only states not enacting such a prohibition are: Ariz., Ga., Idaho, Ky., La., Mass., Nev., N. C., Okla., S. C., Utah, Wis. For an example of this type of prohibition see Fu. Comp. GeN. Laws ANN. (Skillman, Supp. 1936) \$415I(228): “. . . no license shall be issued to a manufacturer ... as a vendor [retailer], nor shall any license be issued to a vendor as a manufacturer. . . ."

${ }^{\circ 8}$ Ala., Calif., Conn., Ind., Me., Mich., Neb., N. J., N. D., R. I., Tenn., Tex., Vt. E.g., Ind. Stat. Ann. (Burns, Supp. 1940) \$r2-515: "No person holding a manufacturer's . . . permit may own . . . any permit to wholesale alcoholic spirituous beverages. ..."

${ }^{D 0}$ Ala., Ark., Calif., Colo., Conn., Del., Fla., Ind., Iowa, Minn., Mo., Neb., N. J., N. Y., N. D., Pa., S. D., Texas, Va., Wash., W. Va., Wyo. ${ }^{100} \mathrm{Ill}$., Md., Mont., N. H., Ore.

${ }^{101}$ Kan., Me., Mich., Miss., N. M., Ohio, R. I., Tenn., Vt. Such language usually reads: "No manufacturer ... may have any interest in the business of any retail dealer." Miss. Code ANN. (Supp. $1938) \$ 2878$.

${ }_{103}$ The Federal Alcohol Administration Act, 49 STAT. 977, 27 U. S. C. A. \$\$207-212 (1935).

${ }^{103}$ Id. $\$ 5(\mathrm{~b})(\mathrm{x}),(2) ;$ id. $\$ 205$.

${ }_{104}$ N. M. Laws 1939, c. $236, \$ \times 405(b)(x)$, (2) prohibiting a producer from acquiring or holding any interest in any license with respect to the premises of a wholesale or retail liquor dealer for the purpose of inducing such dealer to purchase alcoholic beverages from such producer to the exclusion of others. 
Although there is little direct judicial authority on the constitutionality of such prohibitions, it is probable, owing to the unique legal position of the liquor business, that the courts will support them. The judicial attitude taken is that ${ }^{105}$

the liquor traffic is not a lawful business, except as authorized by express legislation of the State; that no one has the natural or inherent right to engage therein. . . . It is placed under the ban of law, and it is ... therefore separated or removed from the natural rights, privileges and immunities of the citizen.

Furthermore, indirect judicial approval of such a prohibition has been expressed in a case ${ }^{106}$ which interpreted the Maryland liquor laws as prohibiting a corporation operating more than one retail drugstore in Baltimore at the time of the law's enactment, from obtaining a renewal of licenses for stores transferred to that corporation after enactment of the statute, even though these stores had been licensed by the transferor. In the course of its opinion the Maryland court said: ${ }^{107}$

Section 22, on transfer of licenses, in terms permits "any" holder of a license" to ... . sell or assign his license and stock in trade. . . . The provision expresses no limitation upon the persons who may receive transfers; but it could not be contended that there are no limitations under the act. In sections 5 (II), 28, and 33 there are elaborate provisions to prevent the holding or control of retail licenses by manufacturers or wholesalers, and section 22 would not be construed to furnish an easy escape by permitting the ownership or control by purchase. ... Transfers would be permitted only to persons not denied a right to hold licenses.

Efforts to prevent ice cream retailers from engaging, by means of the counterfreezer, in the manufacture of ice cream have met with defeat in at least one jurisdiction through judicial condemnation, ${ }^{108}$ and in at least four others through specific legislative recognition of the use of such freezers. ${ }^{100}$ The restrictive efforts had taken the form of attempts to apply to such manufacturing the existing stringent sanitary legislation requiring the sterilization of equipment with live steam, the use of sloping cement floors with a central drain, and detailed pasteurization procedures. ${ }^{110}$ In the Virginia case it was held that the operator of a drugstore counter-

${ }^{105}$ State v. Parker Distilling Co., 236 Mo. 219, 255, 139 S. W. 453, 46I (I9rr). Accord: State v. Wipke, 345 Mo. 283, 133 S. W. (2d) 354 (r939); McCarroll v. Clyde Collins Liquors, I98 Ark. 896, r32 S. W. (2d) 19 (1939); Franklin Stores Co. v. Burnett, 120 N. J. L. 596, I A. (2d) 25 (1938). See also, State Board of Equalization v. Young's Market Co., 299 U. S. 59 (1936).

${ }^{100}$ Baltimore Retail Liquor Package Stores Ass'n, Inc. v. Kerngood, I7r Md. 426, I89 Atl. 209 (1937).

${ }_{107}$ Id. at 432, I89 Atl. at 2II. See also, State v. Krawczak, 217 Wis. 593, 600, 259 N. W. 607,609 (1935), in which the court said, concerning a provision limiting the number of retail beer licenses which any one person could hold, to two: "It is a matter of common knowledge that the purpose of limiting the number of Class B beer licenses to two was to prevent a brewer from establishing a chain of licensed places as was commonly done in pre-prohibition days, the management of which the brewer controlled and in which sales of beer were limited to the brewer's own product."

${ }^{108}$ Robertson v. Commonwealth, I68 Va. 752, 191 S. E. 773 (1937), interpreting VA. CodE ANN. (Supp. 1938) $\$ \times 215$ as inapplicable to counter freezing.

${ }^{100}$ Mich. Stat. ANN. (Henderson, 1936) §12.788; Miss. Laws 1940, c. 120, §105; Mont. Rev. Codes (Anderson \& Wertz, Supp. 1939) \$2620.20(i); W1s. Code (1939) \$970.05.

110 Typical of stringent sanitary regulations for the manufacture of ice cream are ILL. Rev. STAT. (Smith-Hurd, I939) c. $48, \$ 553-57$; R. I. REv. GEN. LAws (1938) c. $260, \$ \$ 3,4,5$. Quite similar to 
freezer was not engaged in the manufacture of ice cream within the contemplation of the statute. In so holding, the court said:111

The specifications for the contents of the various kinds of ice cream, for the pasteurization of the milk used, for the type of building in which the work is to be done, and for the handling, storage, and transportation of ice cream, all convince us that the framers of the statute had in mind operations of a much wider character than those performed by the defendant here.

A great deal of activity, both federal and state, against the integration of production and distribution has also been taking place recently in the motion picture field. The first law to divorce the exhibition of films from their production appeared on the statute books of North Dakota in 1937. ${ }^{112}$ This law, repealed in r939, made it unlawful for any motion picture theater to be operated in the state when owned, controlled, managed or operated, in whole or in part, by any producer or distributor of motion picture films or in which any producer or distributor had any interest, direct or indirect, legal or equitable, through stock ownership or otherwise. Violations of the statute were made subject to injunction or criminal penalties of a maximum fine of $\$$ ro,000, imprisonment for one year, or both. Similar "divorcement" bills have been introduced in the current legislatures of Minnesota and Nebraska, and are now pending. ${ }^{113}$

National legislation with the same purpose was introduced in Congress on April 9, I940. Although hearings were held and the bill reported out of committee, no final action was taken at that session of Congress. ${ }^{114}$ It has, therefore, been reintroduced in the present session. ${ }^{115}$ This federal bill in its prohibitory clause is couched in language almost identical to that of North Dakota. It makes it unlawful for any producer or distributor "engaged in commerce"116 to own, operate or have any interest in, any motion picture theater in any state, territory or the District of Columbia. Furthermore, in the anti-trust suit in equity commenced by the Department of Justice in 1938 against the great theater-owning picture producing companies, ${ }^{117}$ the prayer for relief included a request for "theater divorcement." However, the consent decree entered on November 20, 1940, between the government and the five theater-owning companies, provides for a three-year trial period during which

the Virginia law construed in Robertson v. Commonwealth, supra note 108, these enactments are therefore susceptible to similar judicial interpretation.

111 Robertson v. Commonwealth, supra note 108 , at 756 , 19r S. E. at 775.

${ }^{112}$ N. D. Laws 1937, c. $165, \S \S \mathrm{I}-7$, repealed by N. D. Laws 1939, c. 202.

${ }^{113}$ Minn. S. F. 69, 1941; Neb. L. B. 208, 1941.

114 S. 3735, introduced by Senator Neely on April 9, 1940. Referred to Senate Committee on the Judiciary. Hearings before a sub-committee: April 22, May 16, I940. No final action.

${ }^{116} \mathrm{Re}$-introduced as S. I85 on Jan. 6, r94I. Referred to same committee.

110 "Engaged in commerce" is defined to include transactions whereby films produced in one state are shipped by the producer or a subsidiary or affliated corporation to film laboratories or exchanges in other states, or sold, leased or licensed by the producer at the point of production to a distributor and so shipped to film laboratories or exchanges in other states, and in either case distributed by such exchanges to motion picture theaters. S. $3735, \$ 2(6)$.

${ }^{117}$ U. S. v. Paramount $e t$ al. (D. N. Y., July 20, 1938). 
the government may observe whether other provisions of the decree will make "divorcement" relief unnecessary.

A federal district court, prior to repeal of the North Dakota statute, sustained that law as a valid exercise of the police power of the state. ${ }^{118}$ In doing so, it decided that the act was designed to promote the general welfare of the public by prohibiting practices which might reasonably be conceived as promotive of monopoly and restraints of trade. It made no difference, said the court, that the facts of the present case did not justify a finding that the plaintiffs, motion picture producers, had a monopoly in North Dakota, were threatening to obtain one, or had been guilty of any serious abuses with respect to competitors or to the public in North Dakota. There was ${ }^{119}$

... evidence in the record which justifies an inference of suppression of local competition in states other than North Dakota by producers having affiliated theaters; and ... of the existence of the power and temptation of such producers to engage in practices promotive of monopoly and restraint of trade.

In the opinion of the court, ${ }^{120}$ the existence of such power

when coupled with the opportunity and the temptation to use that power, is . . a sufficient basis for legislative action to prevent the possibility of its exercise. This must certainly be so where there is, in addition, evidence of past aggressions.

Here again, as in the meat-packing cases, one finds the courts recognizing as sufficient justification for enforced non-integration, the existence of the power to engage in monopolistic practices which integration would give.

One other movement worthy of note, in the activity to divorce production from the retailing function, is found in the bill first introduced in Congress in 1937 by Mr. Patman ${ }^{121}$ to divorce chain-retailing from manufacturing by preventing "manufacturers of products from offering for sale and selling the same at retail ... where the effect of so ... selling ... at retail to consumers may be substantially to lessen competition between such manufacturer and his customers, ${ }^{122}$ or tend to create a monopoly in such line of commerce or to injure, destroy or prevent competition by, a customer or customers of such manufacturer...."123 The bill would

${ }^{128}$ Paramount Pictures, Inc. v. Langer, supra note ro, remanded by the Supreme Court of the United States with directions to dismiss because repeal of the statute had rendered the cause moot. 306 U. S. $6 \mathrm{rg}$ ( 2938$)$.

${ }^{110} \mathrm{Id}$. at 900. See also Crescent Cotton Oil Co. v. Mississippi, supra note ro, which approved an outright prohibition upon the operation of both cottonseed oil mills and cotton gins by the same corporation on the ground, among others, that the legislation was designed to prevent practices promotive of monopoly.

${ }^{120} \mathrm{Ibid}$. The court here cites and quotes from the second Swift \& Co. case, supra note 25, at 116: ". . . size carries with it an opportunity for abuse that is not to be ignored when the opportunity is proved to have been utilized in the past." Compare these attitudes with that of the Kansas court in holding the utility anti-merchandising law invalid. Capital Gas \& Electric Co. v. Boynton, supra note 18.

${ }^{121}$ H. R. 4722, 75th Cong., Ist Sess. (1937) introdueed Fcb. 15, 1937. Referred to the House Committee on Interstate and Foreign Commerce. Hearings before a sub-committec: Dec. 1, 2, 3, 1937 and Jan. 4, 5, 6, 1938. No further action.

122 "Customer of such manufacturer" is defined by $\$ 2$ to include only a retail dealer who at any time already is established in the business of offering for sale and selling to consumers commodities produced or manufactured by such manufacturer. ${ }^{128}$ Id. \$3. 
make such activities an "unfair method of competition in commerce" within the meaning of Section 5 of the Federal Trade Commission Act, and would authorize the Commission to proceed against any manufacturer it had reason to believe was using such unfair methods. Possible spread of this idea to state legislative channels is suggested by the fact that a similar bill has been introduced in the present session of the California legislature. ${ }^{124}$

Clearly here the weapon of protective legislation would be wielded in favor of independent merchants as against the large chains. Integration of production and distribution would be prohibited not to all in a given line of distribution but only to those who have "integrated" in the sense of common ownership and control. But the opposing philosophies remain ever the same. A national association of oil wholesalers and distributors expressed itself in support of the Patman bill as follows: $:^{125}$

This association favors the additional principle of severing the manufacturer from wholesaling as well as retailing. ...

The whole history of the integrated companies engaged in marketing has been a continuous series of unfair practices. . . .

Today we have in the tire industry, I understand, a grand scrap between four, five, or six companies for the business. Evidently, eventually the time will come where there is going to be but one. I mean, that is the trend of monopoly and I am wondering why we could not say in advance that these things which tend to create a monopoly shall be stopped?

And in opposition the old, familiar arguments are used: ${ }^{126}$

Finally ... what of its constitutionality? . . . What becomes of the constitutional liberty of the manufacturer to select his own customers, in bona fide transactions not in restraint of trade? That right includes the right to sell direct to consumer if the manufacturer chooses ... And wherein does this bill have any relation to the fostering and promotion of competition, if such be its object? It does not foster and promote competition, but prevents and freezes it. It means that once a manufacturer has sold to a retailer, he cannot thereafter sell to a consumer direct, in that locality, at the same or a lower price. ... Instead of promoting competition, it would freeze business in the hands of the middleman. ...

${ }^{224}$ Further federal agitation along similar lines is revealed in the recent introduction of a "divorcement" bill for petroleum. S. 170, H. R. r402, 77th Cong., rst Sess., Jan. 6, 1941.

${ }^{196}$ Statement of P. E. Hadlick, Secretary and Counsel, National Oil Marketers Ass'n, Hearings before Sub-committee of the House Committee on Interstate and Foreign Commerce on H. $R$. 4722, 75th Cong., 3d Sess. (1937) 67, 68, 7r. See also United States v. Swift \& Co., supra note 25; Paramount Pictures v. Langer, supra note 10; $c$. Capital Gas \& Electric Co. v. Boynton, supra note I8.

${ }_{128}$ Statement of Reynolds Robertson, representing the Warm Air Furnace Manufacturers, Hearings, supra note 125 , at 93 . 